\title{
Bioconversion of Arecanut Husk; Residue to Compost via Microbial Consortia
}

\author{
S.B. Gurumurthy ${ }^{1 *}$, S.V. Patil ${ }^{2}$, T.H. Shankarappa ${ }^{2}$ and A. Prashantha ${ }^{1}$ \\ ${ }^{1}$ College of Horticulture, Sirsi, Karnataka, India \\ ${ }^{2}$ Regional Horticultural Research and Extension Centre, Bengaluru, Karnataka, India \\ University of Horticultural Sciences, Bagalkot \\ *Corresponding author
}

\section{A B S T R A C T}

\section{Keywords}

Aracanut, compost, Microbial consortia, Glyrecidia, Cow dung

\section{Article Info}

Accepted:

17 July 2018

Available Online:

10 August 2018
An experiment was conducted to study the nutrient content of arecanut husk and its composting by employing efficient microbial consortia consisting of cellulolytic and lignolytic fungi and enrichment of compost with beneficial microorganisms viz., free living nitrogen fixer, Azotobacter and phosphate solubilizer at College of Horticulture, Sirsi for three years (2012-13 to 2014-15). The initial C: $N$ ratio of the husk was 84.71 which had decreased to $15.53,18.41$ and 17.92 during 2012-13, 2013-14 and 1014-15 respectively on 90 days after composting with microbial consortia (T3). However, $\mathrm{N}(0.70$ to $1.40 \%), \mathrm{P}$ (0.23 to $0.77 \%), \mathrm{K}$ (1.16 to $1.46 \%), \mathrm{Zn}$ (90 to $135 \mathrm{ppm}), \mathrm{Mn}$ (251 to $277 \mathrm{ppm}$ ), Fe (30 to $60 \mathrm{ppm}$ ) and $\mathrm{Cu} 230$ to $287 \mathrm{ppm}$ ) contents of the compost were found to increase during 90 days composting. The results of the experiment had clearly indicated that the nutrient content of the compost had increased with increase in the age of the compost up to 90 days in arecanut husk residue, inoculated with microbial consortia along with cow dung slurry and glyricidia (T3) as compared to arecanut husk inoculated with microbial consortia along with cow dung slurry and 3\% urea solution (T2) and uninoculated control, cow dung slurry and glyricidia (T1).

\section{Introduction}

The utilization of human and animal solid wastes is of great importance both from the public health and agricultural point of view. Composting is the conversion of the organic fraction of solid waste materials through microbiological processes leading to the production of humus like end product that is used primarily as a soil conditioner. The art of composting is very old but in recent years progress has been made in understanding this biological process (Harshwardhan and Upadyay, 2017). These studies have enabled the production of finished compost which is both valuable and safe from the view point of public health.

There are basically two methods of composting; in the first method, compostable material is placed in pits or in stacks on the ground and the material is turned over at intervals to allow adequate aeration and mixing. This method has proved most 
satisfactory. In the second method, the waste is filled in pits or trenches in layers and allowed to decompose without being turned over during the composting period of 4-6 months (Dumitrescu et al., 2009).

The quality, composition and nature of the wastes available for composting vary widely with the season and region. In villages, the type of waste depends on the type of agriculture, size of the farm, the animals used and the economic condition of the area. In cities, the quantity and quality of waste is determined by the waste products of industry, street sweepings, ash and garbage.

The decomposition of organic matter is brought about by microorganisms which utilize carbon and nitrogen in the waste for synthesizing cellular constituents. The $\mathrm{C} / \mathrm{N}$ ratio is, therefore, an important factor determining the rate and extent of decomposition. When excess of carbon is available, the rate of decomposition is slow. Generally, a C/N ratio of 30-40 is considered as optimum. During decomposition, a part of the carbon is assimilated and a part is oxidized to carbon dioxide. As a consequence, there is a decrease in the $\mathrm{C} / \mathrm{N}$ ratio and this decrease in the $\mathrm{C} / \mathrm{N}$ ratio is a useful index of composting (Geeta et al., 2015). Biological recycling of agricultural residues is a complex process often determined by the type of microorganisms involved in composting. The efficient recycling of agricultural residues could lead to a better management of nutrients in organic farming, which serves the principles, such as building soil fertility, minimal use of non-renewable resources and minimize pollution.

Large quantities of aracanut residues are available in the aracanut growing and processing areas of Karnataka. The decomposition of this vast residue to valuable organic manure is very much essential. This decomposition process management can be controlled by adjusting the composition of the raw materials by mixing in a definite proportion of the organic wastes that are rich in carbon and nitrogen. This allows for the adjustment of $\mathrm{C} / \mathrm{N}$ ratio to desirable extent suitable for microbial decomposition. The Carbon to nitrogen ratio for most decomposing microorganisms is about 30:1. Materials too high in carbon make decomposition inefficient, if will take longer period for the decomposition to complete (Geeta et al., 2015). Therefore, an effort was made to study the composting of arecanut husk waste which is obtained as solid waste generated after the areca was separated from husk.

\section{Materials and Methods}

An experiment was conducted at College of Horticulture at Sirsi from 2012-13 to 2014-15 (December to February) to investigate the effect of microbial consortia on composting and the nutrient content of arecanut husk compost. There were altogether three treatments and each replicated three times. Treatments included were, $\mathrm{T}_{1}$ : un-inoculated control (Cow dung slurry + Glyricidia), $\mathrm{T}_{2}$ : Microbial consortia along with cow dung slurry and 3\% urea solution and $\mathrm{T}_{3}$ : Microbial consortia along with cow dung slurry and glyricidia. The microbial consortia consisting of Asprgillus awamorii, Pleurotus florida, Phanerochaete chrysosporium and Trichoderma viridae were mass produced on potato dextrose broth and used for the study.

The composting was done in a artificially constructed tank of size $10 \mathrm{ft} \times 3 \mathrm{ft} \times 4 \mathrm{ft}$ (L x B $\mathrm{x} \mathrm{H})$ above ground level using bamboo poles and polythene sheet al.,1 along the sides and the bottom layer (Geeta et al., 2015). The holes are created for proper aeration to maintain the aerobic condition. The quantity of substrate used in the investigation was 2.5 
quintals. The substrate, arecanut husk was piled to a height of one foot and the water was sprinkled over the substrate to maintain $60 \%$ moisture holding capacity followed by application of glyricidia as a thin layer @ 6.25 $\mathrm{kg}$ per layer and applied with slurry of microbial consortia@15.5 liters per layer (slurry was prepared by using $25 \mathrm{~kg}$ cow dung diluted with 62.5 liters of water and $250 \mathrm{gm}$ of microbial consortia). These layers are repeated until the tank is filled. Finally, the top layer was pasted with the mixture of cow dung and mud soil and the polythene was covered. Once in a week, the compost tank was sprinkled with water and the substrate was turned up and down once in fortnight. This process was repeated up to 90 days. After 90 days, the compost was enriched with free living nitrogen fixer, Azotobacter and phosphate solubilizer and allowed for 15 days for curing. Observations on organic carbon, available nitrogen $\mathrm{C}$ : $\mathrm{N}$ ratio, available phosphorous, available potassium, available micronutrients such as zinc, manganese, iron and copper were estimated at the day of compost initiation, at 60 and 90 days after inoculation (DAI) by following standard methods given by Jackson (1973).

\section{Results and Discussion}

In the present investigation, the nutrient contents of the compost had increased from its initial values viz., $\mathrm{N}(0.70$ to $1.40 \%), \mathrm{P}(0.23$ to $0.77 \%), \mathrm{K}$ (1.16 to $1.46 \%), \mathrm{Zn}$ (90 to $135 \mathrm{ppm}$ ), Mn (251 to $277 \mathrm{ppm}$ ), Fe (30 to $60 \mathrm{ppm}), \mathrm{Cu} 230$ to $287 \mathrm{ppm}$ ) with increase in the duration of the compost as recorded on 60 and 90 DAI in the treatments receiving microbial consortia along with cow dung slurry and glyricidia leaves $\left(\mathrm{T}_{3}\right)$ as compared to husk inoculated with microbial consortia along with cow dung slurry and 3\% urea solution $\left(\mathrm{T}_{2}\right)$ and un-inoculated $\left(\mathrm{T}_{1}\right)$ control (cow dung slurry and glyricidia leaves) (Tables 1 to 4 ) recorded in all the three years.
However, the initial $\mathrm{C}: \mathrm{N}$ ratio of the husk was 84.71, which had decreased to $15.53,18.41$ and 17.92 during 2012-13, 2013-14 and 201415 respectively on 90 days after inoculation with microbial consortia (T3) as compared to $\mathrm{T}_{2}$ and un-inoculated control ( $\left.\mathrm{T}_{1}\right)$ (Fig.1).

Organic residues were decomposed by a variety of mixed microbial population. Since the process of decomposition takes place at different phases, better regulation and management achieved through utilization of specific microbial groups for improved finished product.

Using thermophillic microbial isolates a better control over the mechanism of decomposition is obtained which greatly influences the rate of decomposition. Similar increase in nutrient content and decrease in the $\mathrm{C}$ : $\mathrm{N}$ ratio of the compost was reported by Ahmad et al., (2007): Pan et al., (2012); Atalia et al., (2015). The rate of decomposition of aracanut residue or wastes was enhanced by inoculation of an efficient group of degradative microorganisms.

The major chemical component in the organic matter is either lignocelluloses in agricultural wastes and starch, protein and fats in the urban solid organic wastes. Development of a microbial consortium for rapid degradation reduces the time of decomposition as well as increases the population density an indication of quality improvement.

Decomposed organic matter from heterogenous waste is low in nutrient content. During the process management the concentration of major and minor nutrient elements can be improved. Similarly, the nutrient status of arecanut compost was enriched. Where, the decomposing substrate was mixed with green glyrecidia plant residue in a suitable proportion to adjust the $\mathrm{C} / \mathrm{N}$ ratio to about 40 (Ekinci et al., 2002). 
Table.1 Organic carbon and total nitrogen status of arecanut compost as Influenced by microbial consortia

\begin{tabular}{|c|c|c|c|c|c|c|c|c|c|c|c|c|c|} 
Treatments & \multicolumn{9}{|c|}{ Organic carbon (\%) } & \multicolumn{1}{c|}{ Total Nitrogen $(\%)$} \\
& \multicolumn{2}{|c|}{$2012-13$} & \multicolumn{2}{|c|}{$2013-14$} & $2015-16$ & $2012-13$ & $2013-14$ & $2014-15$ \\
& 60 & 90 & 60 & 90 & 60 & 90 & 60 & 90 & 60 & 90 & 60 & 90 \\
& DAI & DAI & DAI & DAI & DAI & DAI & DAI & DAI & DAI & DAI & DAI & DAI \\
\hline T1 & 55.50 & 48.60 & 56.70 & 54.70 & 54.30 & 50.30 & 0.80 & 1.00 & 0.87 & 1.26 & 0.86 & 1.23 \\
\hline T2 & 55.20 & 44.20 & 55.70 & 42.30 & 52.60 & 42.70 & 1.29 & 1.30 & 1.29 & 1.30 & 1.30 & 1.31 \\
\hline T3 & 43.80 & 21.60 & 40.30 & 25.60 & 39.50 & 25.10 & 1.35 & 1.39 & 1.31 & 1.39 & 1.34 & 1.40 \\
\hline
\end{tabular}

Note: Initial Organic Carbon $=59.30 \%$; Initial Total Nitrogen $=0.70 \%$; DAI $=$ Days after inoculation

$\mathrm{T}_{1}$ : Cow dung slurry + Glyricidia; $\mathrm{T}_{2}$ : Microbial consortia + Cow dung slurry $+3 \%$ urea

$\mathrm{T}_{3}$ : Microbial consortia + Cow dung slurry + Glyricidia

Table.2 Phosphorous and potassium status of arecanut compost as Influenced by microbial consortia

\begin{tabular}{|c|c|c|c|c|c|c|c|c|c|c|c|c|}
\hline \multirow[t]{3}{*}{ Treatments } & \multicolumn{6}{|c|}{ Total Phosphorous (\%) } & \multicolumn{6}{|c|}{ Total Potassium (\%) } \\
\hline & \multicolumn{2}{|c|}{$2012-13$} & \multicolumn{2}{|c|}{ 2013-14 } & \multicolumn{2}{|c|}{$2015-16$} & \multicolumn{2}{|c|}{$2012-13$} & \multicolumn{2}{|c|}{ 2013-14 } & \multicolumn{2}{|c|}{ 2014-15 } \\
\hline & $\begin{array}{c}60 \\
\text { DAI }\end{array}$ & $\begin{array}{c}90 \\
\text { DAI }\end{array}$ & $\begin{array}{c}60 \\
\text { DAI }\end{array}$ & $\begin{array}{c}90 \\
\text { DAI }\end{array}$ & $\begin{array}{c}60 \\
\text { DAI }\end{array}$ & $\begin{array}{c}90 \\
\text { DAI }\end{array}$ & $\begin{array}{c}60 \\
\text { DAI }\end{array}$ & $\begin{array}{c}90 \\
\text { DAI }\end{array}$ & $\begin{array}{c}60 \\
\text { DAI }\end{array}$ & $\begin{array}{c}90 \\
\text { DAI }\end{array}$ & $\begin{array}{c}60 \\
\text { DAI }\end{array}$ & $\begin{array}{c}90 \\
\text { DAI }\end{array}$ \\
\hline $\mathrm{T1}$ & 0.427 & 0.50 & 0.236 & 0.563 & 0.24 & 0.53 & 1.20 & 1.30 & 1.21 & 1.30 & 1.19 & 1.30 \\
\hline T2 & 0.562 & 0.59 & 0.563 & 0.60 & 0.57 & 0.63 & 1.21 & 1.32 & 1.21 & 1.33 & 1.24 & 1.30 \\
\hline T3 & 0.63 & 0.71 & 0.65 & 0.72 & 0.64 & 0.77 & 1.36 & 1.39 & 1.37 & 1.40 & 1.35 & 1.46 \\
\hline
\end{tabular}

Note: Initial Total Phosphorous $=0.239 \%$; Initial Total Potassium $=1.160 \%$; DAI $=$ Days after inoculation

$\mathrm{T}_{1}$ : Cow dung slurry + Glyricidia; $\mathrm{T}_{2}$ : Microbial consortia + Cow dung slurry $+3 \%$ urea

$\mathrm{T}_{3}$ : Microbial consortia + Cow dung slurry + Glyricidia

Table.3 Zinc and manganese status of arecanut compost as influenced by microbial consortia

\begin{tabular}{|c|c|c|c|c|c|c|c|c|c|c|c|c|}
\hline \multirow[t]{4}{*}{ Treatments } & \multicolumn{6}{|c|}{ Total Zinc (ppm) } & \multicolumn{6}{|c|}{ Total Manganese (ppm) } \\
\hline & \multicolumn{2}{|c|}{$2012-13$} & \multicolumn{2}{|c|}{ 2013-14 } & \multicolumn{2}{|c|}{$2015-16$} & \multicolumn{2}{|c|}{$2012-13$} & \multicolumn{2}{|c|}{ 2013-14 } & \multicolumn{2}{|c|}{$2014-15$} \\
\hline & 60 & 90 & 60 & 90 & 60 & 90 & 60 & 90 & 60 & 90 & 60 & 90 \\
\hline & DAI & DAI & DAI & DAI & DAI & DAI & DAI & DAI & DAI & DAI & DAI & DAI \\
\hline $\mathrm{T1}$ & 109 & 113 & 94 & 116 & 91 & 114 & 268 & 270 & 267 & 271 & 270 & 273 \\
\hline $\mathrm{T2}$ & 118 & 121 & 119 & 124 & 118 & 126 & 269 & 270 & 270 & 275 & 274 & 278 \\
\hline T3 & 128 & 133 & 127 & 135 & 130 & 135 & 271 & 274 & 272 & 274 & 275 & 277 \\
\hline
\end{tabular}

Note: Initial Total Zink $=90 \mathrm{ppm}$; Initial Total Manganese $=251 \mathrm{ppm} ; \mathrm{DAI}=$ Days after inoculation

$\mathrm{T}_{1}$ : Cow dung slurry + Glyricidia; $\mathrm{T}_{2}$ : Microbial consortia + Cow dung slurry $+3 \%$ urea

$\mathrm{T}_{3}$ : Microbial consortia + Cow dung slurry + Glyricidia

Table.4 Iron and copper status of arecanut compost as influenced by microbial consortia

\begin{tabular}{|c|c|c|c|c|c|c|c|c|c|c|c|c|}
\hline \multirow[t]{3}{*}{ Treatments } & \multicolumn{6}{|c|}{ Total Iron (ppm) } & \multicolumn{6}{|c|}{ Total Copper (ppm) } \\
\hline & \multicolumn{2}{|c|}{$2012-13$} & \multicolumn{2}{|c|}{ 2013-14 } & \multicolumn{2}{|c|}{$2015-16$} & \multicolumn{2}{|c|}{$2012-13$} & \multicolumn{2}{|c|}{ 2013-14 } & \multicolumn{2}{|c|}{$2014-15$} \\
\hline & $\begin{array}{c}60 \\
\text { DAI }\end{array}$ & $\begin{array}{c}90 \\
\text { DAI }\end{array}$ & $\begin{array}{c}60 \\
\text { DAI }\end{array}$ & $\begin{array}{c}90 \\
\text { DAI }\end{array}$ & $\begin{array}{c}60 \\
\text { DAI }\end{array}$ & $\begin{array}{c}90 \\
\text { DAI }\end{array}$ & $\begin{array}{c}60 \\
\text { DAI }\end{array}$ & $\begin{array}{c}90 \\
\text { DAI }\end{array}$ & $\begin{array}{c}60 \\
\text { DAI }\end{array}$ & $\begin{array}{c}90 \\
\text { DAI }\end{array}$ & $\begin{array}{c}60 \\
\text { DAI }\end{array}$ & $\begin{array}{c}90 \\
\text { DAI }\end{array}$ \\
\hline T1 & 44 & 48 & 45 & 47 & 48 & 50 & 248 & 251 & 249 & 253 & 251 & 255 \\
\hline$\overline{T 2}$ & 49 & 52 & 52 & 53 & 51 & 55 & 255 & 268 & 254 & 270 & 253 & 273 \\
\hline$\overline{T 3}$ & 52 & 58 & 54 & 59 & 56 & 62 & 283 & 287 & 285 & 285 & 284 & 287 \\
\hline
\end{tabular}

Note: Initial Total Iron $=30 \mathrm{ppm}$; Initial Total Copper $=230 \mathrm{ppm}$; DAI $=$ Days after inoculation

$\mathrm{T}_{1}$ : Cow dung slurry + Glyricidia; $\mathrm{T}_{2}$ : Microbial consortia + Cow dung slurry $+3 \%$ urea

$\mathrm{T}_{3}$ : Microbial consortia + Cow dung slurry + Glyricidia 
Fig.1 The $\mathrm{C}$ : $\mathrm{N}$ ratio of arecanut compost as influenced by microbial consortia

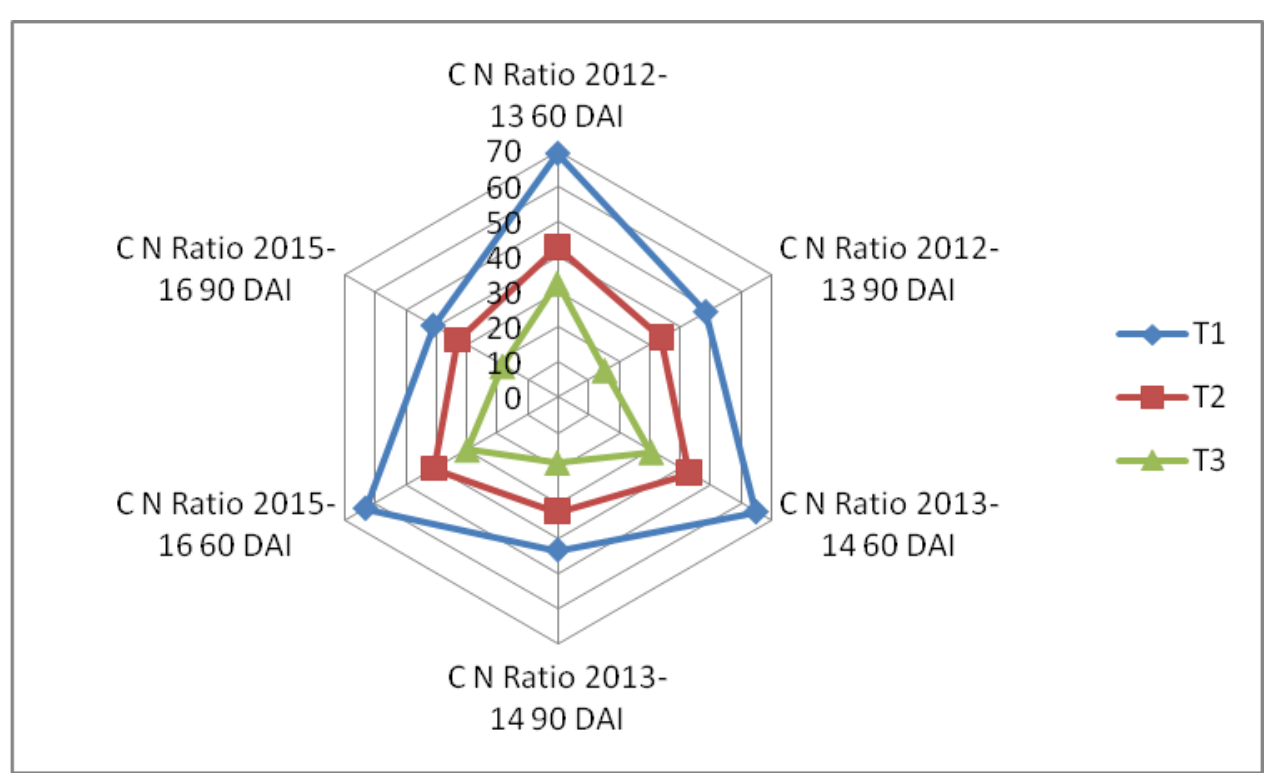

Note: Initial C: $\mathrm{N}$ ratio 84.71; Initial Total Nitrogen $=0.70 \%$; DAI= Days after inoculation

$\mathrm{T}_{1}$ : Cow dung slurry + Glyricidia

$\mathrm{T}_{2}$ : Microbial consortia + Cow dung slurry $+3 \%$ urea

$\mathrm{T}_{3}$ : Microbial consortia + Cow dung slurry + Glyricidia

This mixture had supported for rapid microbial growth and enhanced the beneficial microbial population, which in turn increased the nutrient content of the organic manure prepared. Addition of rock phosphate to the decomposing organic matter along with a phosphate solubilizing microorganisms brings about solubilization of insoluble phosphorous and increases the availability of plant available phosphorous (Geeta et al., 2015). Fungal cultures which are added as consortia during the process of decomposition acts as an activator to hasten the process of decomposition (Pfotzer and Schuler, 1997). Use of thermophillic microbial inoculums influences the efficiency of the process acceleration. This results in the faster rate of mineralization with a subsequent establishment of the beneficial microbial population density (Diwakaran and Elango, 2009).

Adding an efficient nitrogen fixing bacteria and a phosphate solubilizing microorganism enhance the degradative potential of the microbial community. The characteristic of the inoculated population could bring about decomposition of organic matter at faster rates throughout the process. The higher population density imparts, through their metabolic activity the plant growth promotional property by production of growth hormones and also acts as biological control agents against soil borne root pathogens. The process management of organic matter decomposition requires the development of a suitable, effective microbial consortium which through their metabolic activity bring about the bioconversion and accumulation of plant growth promoting substances including the nutrients required for crop production and to sustain the progressive soil fertility status (Diwakaran and Elango, 2009; Geeta et al., 2015). The decomposed organic matter through proper management results in the production of a microbial enriched organic manure. Agriculturally, these high quality organic manures are the important 
components in organic farming system as a source of plant nutrients, as soil conditioners and for maintenance of soil health by suppressing the soil borne pathogens. Environmentally this microbial mediated organic matter finds an effective use in process for bioremediation of soil.

The arecanut husk residue was decomposed in three months period when inoculated with consortia of decomposing fungi, further enrichment with nitrogen fixer and phosphate solubilizing bacteria could result in to production of nutrient enriched compost. Therefore microbial consortia, cow dung slurry and glyrecidia could be efficiently used for production of arecanut compost in quick time.

\section{References}

Ahamad, R., Jilani, G., Arshad, M., Zahir, Z. A. and Khalid, A. 2007. Bioconversion of organic wastes for their recycling in agriculture: an overview of perspectives and prospects. Annals of Microbiology, 57(4): 471-479.

Atalia, K. R., Buha, D. M., Bhavsar, K. A. and Shah, N. K. 2015. A review on composting of municipal solid wastes. J. Environ. Sci. Toxicol. Food Tech. 9(5): 20-29.

Diwakaran, J. and Elango, R. 2009. Microbial consortium for effective composting of coffee pulp waste by enzymatic activities. Global J. Env. Res. 3(2): 9295.

Dumitrescu, L., Manciulea, I., Sauciuc, A. and Zaha, C 2009. Obtaining fertilizer compost by composting vegetable waste, sewage sludge and sawdust. In: Bulletin of the Transilvania. 2(51). University of Braşov, pp 117-122.

Ekinci, K., Keener, H. M. and Elwell, D. L. 2002. Composting short paper fiber with broiler litter and additives II . Evaluation and optimization of decomposition rate versus mixing ratio. Compost Science and Utilization, 10: 16-28.

Geeta, G. S., Ashwini, M. and Shankarappa, T. H. 2015. Management of biogas spent slurry for hastening the composting of agro residues. Carbon Sci. Tech. 7(2): 25-32.

Harshwardhan, K. and Upadhyay, K. 2017. Effective utilization of agricultural waste: Review. J. Fundam. Renewable Energy Appl., 7: 237.

Jackson, M. L., 1973. Soil chemical analysis. Prentice hall India Pvt. Ltd., New Delhi.

Pan, L. Dam, B. and Sen, S. K. 2012. Composting of common organic wastes using microbial inoculants. Biotech. 2(2): 127-134.

Pfotzer, H. and Schuler, C. 1997. Effects of different compost amendments on soil biotic and faunal feeding activity in an organic farming system. Biological Agriculture Horticulture, 15:177-183. 1997.

\section{How to cite this article:}

Gurumurthy, S.B., S.V. Patil, T.H. Shankarappa and Prashantha, A. 2018. Bioconversion of Arecanut Husk; Residue to Compost via Microbial Consortia. Int.J.Curr.Microbiol.App.Sci. 7(08): 2883-2888. doi: https://doi.org/10.20546/ijcmas.2018.708.305 